\title{
BIOACCUMULATION OF SOME HEAVY METALS IN EISENIA FOETIDA
}

\section{CULTURED IN INDUSTRIAL WASTE}

\author{
S. A. Pathak ${ }^{1}$, R. V. Didolkar ${ }^{1}$ and V. K. Didolkar ${ }^{2}$ \\ ${ }^{1}$ Department of Zoology, L. .A. .D. and Smt R. .P. College for Women, \\ Nagpur Maharashtra (INDIA) \\ ${ }^{2}$ M. M. E., V. N. I. T., Nagpur \\ Email: 1'sadhanamshr@gmail.com,1rvdidolkar@gmail.com, \\ 2vkdidolkar@mme.vnit.ac.in
}

\begin{abstract}
Present work was aimed to evaluate the possible occurrence of hazardous wastes on vermicomposting and bioaccumulation using Eisenia foetida. Industrial soils contain heavy metals in variable proportions and accumulate in the body of soil organisms such as E. foetida. These heavy metals are toxic and non-degradable and cause serious effects on ecosystem. Present work focuses the effects of industrial waste on bioaccumulation of heavy metals like Manganese, Lead, Nickel and Cadmium. The experiment was conducted using garden soil (Group-I) and three other Industrial waste soils which consisted of Mahananda dairy soil (Group-II), Mahananda dairy ash(GroupIII) and Western Coalfield Ltd. seepage soil (Group-IV). Fifty earthworms were introduced in each group. Experiments were run for fifty days and bioaccumulation studies were carried out following 30 days, 40 days, and 50 days respectively. Studies indicated presence of heavy metals such as Lead, Nickel and Cadmium in all the samples of soil in which the earthworms were cultured. Highest concentration of Manganese was noted in Group III soil followed by Group IV, Group I and Group II respectively. There was no bioaccumulation of Lead, Nickel, and Cadmium in earthworms in any of the groups of industrial wastes studied. Manganese was days.

Key Words: Industrial waste, Vermicomposting, Bioaccumulation, Eisenia foetida, Heavy metals .
\end{abstract}

\section{Introduction}

Bioaccumulation is an important process through which chemicals can affect living organisms. Bioaccumulation means an increase in the concentration of chemical or toxic elements in a biological organism over the time, compared to the chemical concentration in the environment. Bioaccumulation begins when the toxic element passes from the environment into an organisms' cell. Earthworms can be used as 
indicators of metal pollution since they accumulate heavy metals in their tissues. Use of these worms in agriculture is wellknown. In the present study soils from four different sites have been used to culture the earthworms and to study their possible survival. It has been reported that contaminated soils have become a primordial problem since they lead to groundwater contamination and biomagnifications of chemical compound through food webs and affect human health ( 1 ). Heavy metals are essential for optimum crop production. However they also act as toxicants to soil and soil orgaqnisms and crops at elevated concentrations. It has been reported that heavy metals such as $\mathrm{Mn}, \mathrm{Ni}$, and $\mathrm{Cd}$ are required at micro level for optimum crop performance (2), (3).The major pathways of heavy metals into the soil are mainly through application of compost and chemical fertilizers(4). They affect growth, morphology and metabolism of microorganisms in soil as they cause protein denaturation or the destruction of the integrity of cell membranes. Besides the metals of lithogenic origin, sources resulting from different human activities such as mining, metallurgy, combustion of fossil energy sources, solid waste or sewage sludge disposal, animal effluents and fertilizer inputs for agriculture are deposited on soil. Manganese, Lead, Nickel, Cadmium are the heavy metals which are toxic in nature in high concentrations(5). As is evident from literature Cadmium is toxic to every system of the body, taken in via any route. It is well known cumulative poison in animals. It is classified as the second most dangerous metal in our environment (6). Cd has impact on soil microbiological activity, which plays a major role in soil metabolism, thus affecting soil fertility (7).Various studies have noted that the distribution of metals among the soil phases is important for the bioaccumulation by earthworms (8). They are able to accumulate high tissue concentration of trace metals from metal contaminated soils (9). 


\section{Objectives}

Objective of the present work was to study the bioaccumulation of heavy metals such as Manganese, Lead, Nickel, and Cadmium grown in industrial waste soils, and in earthworm Eisenia foetida cultured in these soils.

\section{Materials and methods}

Present experiment was carried out in epigeic earthworm Eisenia foetida. The animals were collected from Go-Vigyan Anusandhan Kendra, Devlapar, district Nagpur. Prior to the set up the earthworms were acclimatized to the laboratory conditions with sufficient aeration and with basic requirements such as soil, moisture, etc. Four types of soils were used in the present experiment which included garden soil (B-I), Mahananda dairy soil(B-II), Mahananda dairy ash(B-III),Western Coalfields Ltd. seepage soil(B-IV), and Diffusion Engineers Ltd. Sludge(BV).

Five groups of experimental animals were prepared for undertaking this work. Group 1 consisted of garden soil (B-I); Group 2 with Mahananda dairy soil(B-II); Group 3 with Mahananda dairy ash (B-III) and Group 4( B-IV) with the Western coalfields Ltd. seepage soil. Plastic buckets were used to carry out the experiment. The buckets were perforated at the bottom and were filled with broken pieces of bricks and other materials as given in Table 1.This soil was moistened by sprinkling water. Fifty earthworms measuring approximately between $6.5 \mathrm{~cm}$ to $8 \mathrm{~cm}$ were washed with glass distilled water and were introduced in each of the buckets. Observations were made following 30, 40, and 50 days.

Table 1 Materials required for experiment

\begin{tabular}{|c|c|c|}
\hline S. No & Constituents used for & Quantity \\
\hline 1 & Bricks & $6 \mathrm{~cm}$ \\
\hline 2 & Soil layer & $2.5 \mathrm{~kg}$ per group \\
\hline 3 & Cow dung slurry & $500 \mathrm{ml}$ \\
\hline 4 & Vegetables & $100 \mathrm{~g}$ per group \\
\hline 5 & Earthworms & 50 per group \\
\hline
\end{tabular}


Analysis of soil samples: $10 \mathrm{~g}$ of soil sample was taken from each group and allowed to dry at room temperature It was passed through a $2 \mathrm{~mm}$ sieve, $5 \mathrm{~g}$ of sieved soil sample from each group was weighed and $10.0 \mathrm{ml}$ nitric acid was added to it. The mixture was taken in a round bottom flask with a condenser and refluxed for 45 minute. The contents in the flask were evaporated to dryness and $5.0 \mathrm{ml}$. Aqua regia was added to it and the contents were again evaporated to dryness after which $10.0 \mathrm{ml}$ nitric acid was added and suspension was filtered. The filtrate was diluted with glass distilled water in a $100.0 \mathrm{ml}$ volumetric flask and was processed for estimation of heavy metals in Atomic Absorption Spectrophotometer for Manganese, Lead, Nickel, and Cadmium.

Preparation of earthworms for bioaccumulation : Five earthworms from each group were taken out and kept in a beaker with a Whatman filter paper for 24 hours in refrigerator to purge soil in the gut. They were removed and dried at 80 degree Celsius for 24 hours and then powered. The powder was preserved in air tight containers until analysis. Known quantity of earthworm powder from each Group was taken in a beaker and was digested in 2:1 mixture of nitric acid and per chloric acid until dryness. The content was dissolved in $10.0 \mathrm{cc}$ of hydrochloric acid and distilled water(1:1). This was further diluted to $100.0 \mathrm{ml}$ with distilled water in a volumetric flask. This was used for bioaccumulation studies on AAA GBC Scientific equipment Australia SensAA Dual (11).

\section{Results}

Table 2 shows heavy metal concentrations in soil samples in four groups studied. Maximum concentration of manganese was noted in group B-III followed by lesser concentrations in group B-IV, B-I and B-II respectively in that order. Maximum lead concentration was noted in B-IV followed by lesser concentration in B-II, B-III and B-I respectively. Nickel concentration was found to be highest in group B-III, followed by B-IV, B- 
II and B-I respectively. Cadmium concentration was highest in group BIII followed by B-II,B-IV and B-I respectively. It was noted that soil from Mahananda Dairy Ash had maximum concentrations of $\mathrm{Mn}, \mathrm{Ni}$ and $\mathrm{Cd}$.

Table 2 Heavy metal concentrations in soil samples in various groups.

\begin{tabular}{|cc|c|c|c|c|}
\hline \multirow{2}{*}{$\begin{array}{c}\text { Sample } \\
\text { Soil }\end{array}$} & \multicolumn{4}{|c|}{ Concentration (ppm) } \\
\cline { 2 - 6 } & Mn & Pb & Ni & Cd \\
\hline B- & I & 4.174 & 0.013 & 0.168 & 0.117 \\
\hline B- & II & 0.890 & 0.178 & 0.309 & 0.141 \\
\hline B- & III & 17.353 & 0.166 & 0.942 & 0.167 \\
\hline B- & IV & 5.523 & 0.327 & 0.514 & 0.123 \\
\hline
\end{tabular}

Heavy metal concentrations in Eisenia foetida are given in

Table 3. Maximum concentration of Mn was observed in group B-I and the concentrations were noted to be in the order B-I>B-II $>$ B-IV $>$ B-III following 30 days. After 40 days there was 100\% mortality of earthworms in group B-III. The Mn concentrations in earthworm was highest in B-I followed by B-IV and B-II respectively.After 50 days bioaccumulation was found to be highest in B-I followed by in B-IV. There was no significant accumulation of other metals like $\mathrm{Ni}, \mathrm{Pb}$, and $\mathrm{Cd}$ through trace amounts of $\mathrm{Ni}$ were observed in B-I following 40 days and no accumulation was noted in B-II. Physicochemical characteristics with respect to each group have been summarized in Table 4. It is observed that the Nitrate nitrogen concentration was noted to be between range $0-5$ that is low in B-III which apparently are not suitable for vermicomposting.

Table 3 Heavy metal concentration in $E$. foetida in various groups.

\begin{tabular}{|c|c|c|c|c|c|}
\hline Exp. Days & $\begin{array}{c}\text { Sample } \\
\text { (Earthworm) }\end{array}$ & $\mathbf{M n}$ & $\mathbf{N i}$ & $\mathbf{P b}$ & $\mathbf{C d}$ \\
\cline { 2 - 6 } & & 1.385 & 0.000 & 0.000 & 0.004 \\
\hline \multirow{3}{*}{30} & BI & 0.802 & 0.000 & 0.000 & 0.000 \\
\cline { 2 - 6 } & BII & 0.163 & 0.000 & 0.000 & 0.000 \\
\cline { 2 - 6 } & BIII & 0.540 & 0.000 & 0.000 & 0.000 \\
\hline \multirow{3}{*}{40} & BIV & 2.350 & 0.041 & 0.000 & 0.000 \\
\cline { 2 - 6 } & BI & 0.741 & 0.000 & 0.000 & 0.000 \\
\cline { 2 - 6 } & BII & 0.836 & 0.000 & 0.000 & 0.000 \\
\hline \multirow{3}{*}{50} & BIV & 1.820 & 0.000 & 0.000 & 0.003 \\
\cline { 2 - 6 } & BI & Nil & 0.000 & 0.000 & 0.000 \\
\cline { 2 - 6 } & BII & 0.519 & 0.000 & 0.000 & 0.008 \\
\hline
\end{tabular}


Table 4 Physico-chemical characteristics of soil

\begin{tabular}{|c|c|c|c|}
\hline Groups & $\mathrm{pH}$ & Organic Carbon & Nitrate nitrogen \\
\hline B-I & 7.5 & $<0.5 \%$ & $5-10 \mathrm{M}$ \\
\hline B-II & 6 & $>0.75 \%$ & $15-20 \mathrm{H}$ \\
\hline B-III & 7.5 & $0.5 \%-0.75 \%$ & $0-5 \mathrm{~L}$ \\
\hline B-IV & 8 & $0.5 \%-0.75 \%$ & $0-5 \mathrm{~L}$ \\
\hline
\end{tabular}

\section{Discussion}

It is evident from the present study that the heavy metals present in the contaminated soil were bioaccumulated in the tissues of earthworms. Such observations were also made by Kennette and Hendershot(10).We found that manganese was present in all group of soil due to high availability of this metal in the soil. While availability of heavy metals such as Lead, Nickel, and Cadmium was observed to be very low in control soil, it was observed that there was no bioaccumulation of these metals in the earthworms. It has also been reported that the amount of metals accumulated within the earthworm is partly dependent on the absolute concentration of metals within a given soil sample and physicochemical interactions. (11). However in the present studies maximum concentration of $\mathrm{Mn}$ was noted in Group B-I following 30, 40 and 50 days. It has been reported that earthworms have high metabolic and defecation rate for some metals. A positive correlation has been noted between soil Cadmium concentration in soil and $\mathrm{Cd}$ accumulation in Lumbricus rubellus (12) However it was noted that no such correlation was seen with respect to $\mathrm{Cd}$ in the present study. While low availability of metals such as $\mathrm{Ni}$ and $\mathrm{Pb}$ has been noted in soil there was no bioaccumulation of these metals (13), thus in the present study however, no such correlation could be shown as far as $\mathrm{Pb}$ and $\mathrm{Ni}$ concentrations are concerned. Positive correlation has been reported with respect to the heavy metal concentration in earthworms and the total concentration of heavy metals in soils(14) and the earthworms are widely used as indicators of soil polluition. There was a high $\mathrm{Mg}$ 
concentration in the soils in various groups as well as high $\mathrm{Mg}$ bioaccumulations in E. foetida in the present study. However high levels of $\mathrm{Ni}$ and $\mathrm{Cd}$ were noted in Group B III soils which appeard to be toxic to the earthworms since there was no survival of earthworms in soils from group B-III. High concentrations of heavy metal such as $\mathrm{Zn}$ also appear to be toxic to earthworms as they resulted in $96 \%$ mortality following 30 days which indicated that this waste was not suitable for vermicomposting. (15). Study of physicochemical characteristics of soils of various groups indicated low nitrate nitrogen as is evident from Table 4. It appears that the high metal concentrations along with the low nitrate nitrogen might have led to mortality of earthworms in Group B III.

\section{Conclusions}

Bioaccumulation studies with respect to heavy metals revealed that there was accumulation of metals such as $\mathrm{Mn}, \mathrm{Ni}, \mathrm{Pb}$ And $\mathrm{Cd}$ in all the soil samples studied. No survival of E. foetida was noted in Group B III following forty days which indicated that this industrial soil was not suitable for vermicomposting. There was some correlation noted between the heavy metal concentration of soil and the bioaccumulation in $E$. foetida in some groups studied.

\section{References}

Loureiro. S. Soares, A.M.V.M and Nogueira, A.J.A. (2005) Terrestrial avoidance behavior tests as screening tool to asses soil contamination. Environ. Pollut. 138 ; 121 - 131

Nabulo, G. Oryem origa, H; Nasinyama, G. W; Cole, D., (2008) Assessment of $\mathrm{Zn}, \mathrm{Cu}, \mathrm{Pb}$, and $\mathrm{Ni}$ contamination in Wetland. Soils and plants in the lake basin. Int. J. Environ. Sci. Tech, 5(1). $65-74$.

Shylar, H, McBride, M. and Harrison, E (2009). Soil contamination and best practices for healthy gardens. Cornell University Dept. of Crop and Soil Sciences journal pp 25- 35 
Rosen, C. J (2002). Contaminants in the home garden and urban soil environment. Extension Guide, University of $\mathrm{M}$ innesota Extension Services, Department of soil, Water and Climate pp $210-216$

Harris, R. C. and Hohenemser, C. (1978) Mercury measuring and managing the risk. Environ., $20: 25$ - 36

Brookes, P.C. (1995) The use of microbial parameters in monitoring soil polluting by heavy metals. Biol. Fertil. Soils 19: 269-279

Weltje, L. (1998) Mixture toxicity and tissue interactions of $\mathrm{Cd}, \mathrm{Cu}$, $\mathrm{Pb}$, and $\mathrm{Zn}$ in earthworm (Oligochaeta) in laboratory and field soils: a critical evaluation of data. Chemosphere36: 2643-2660.

Morgan, J.E. and Morgan, A.J. (1998) The distribution and intracellular compartmentation of metal in the endogeic earthworm Aporrectodea caliginosa sampled from an unpolluted and a metal contaminated site. Environ. Pollut. 99, 167 - 175.

Ma, W.C: Edleman, I: Van Beersum; Th. Jane. (1983). Uptake of cadmium, zinc, lead zinc smelting complex. Influence of soil $\mathrm{pH}$ and organic matter. Bull. Environ. Cotnam. Toxicol 30, 424 427

Kennette, D, Hendershot, W; Tomlin, A. Sauve, S (2000). Uptake of trace metals by the earthworm Lumbricus terrestris $t$ in urban contaminated Soil. Applied soil Ecology 19, 191 -198 
Atulegwu Patrick uzoije, Luke uzoiigwe, Erick otounye, Clifford O Kamalu , Austine Onunkwo-Akunne (2013). Modelling Lateral Distribution of Heavy Metal and Bio-accumulation in Earthworm in the Varying Acidic Surface Horizon of Waste- Polluted Soil, International Journal of Energy Engineering DOI: 10.5923/j.ijee.2013030202, 3(2): 45-54

P.H.F. Hobbelen, J.E. Koolhaa,C.A.M. van Gestels (2006) Bioaccumulation of heavy metals in the earthworms L..rubellus and Aporectodea caliginosa in relation to total and available metal concentrations in field soils Environmental Pollution 144, 639-646

An experimental marine response to crude oil and Corexit 9527. (1984) Marine Environmental Reaseach, Volume 13, issue 4, 265-275.

Sadhana A. Pathak, Ragini V. Didolkar, and V. K. Didolkar (2013). Role of earthworms in minimizing indusrial waste. Paper presented at the National conference on recent developments in ecofriendly materials ECOMAT-2013 In Press.

Stafford, E.A. and Mc. Grath, S.P. (1986). The use of acid insoluble residue to correct for the presence of soil derived metals in the gut of earthworms used as bio-indicator organisms. Environ. Sci. Tech, $20,151-155$. 